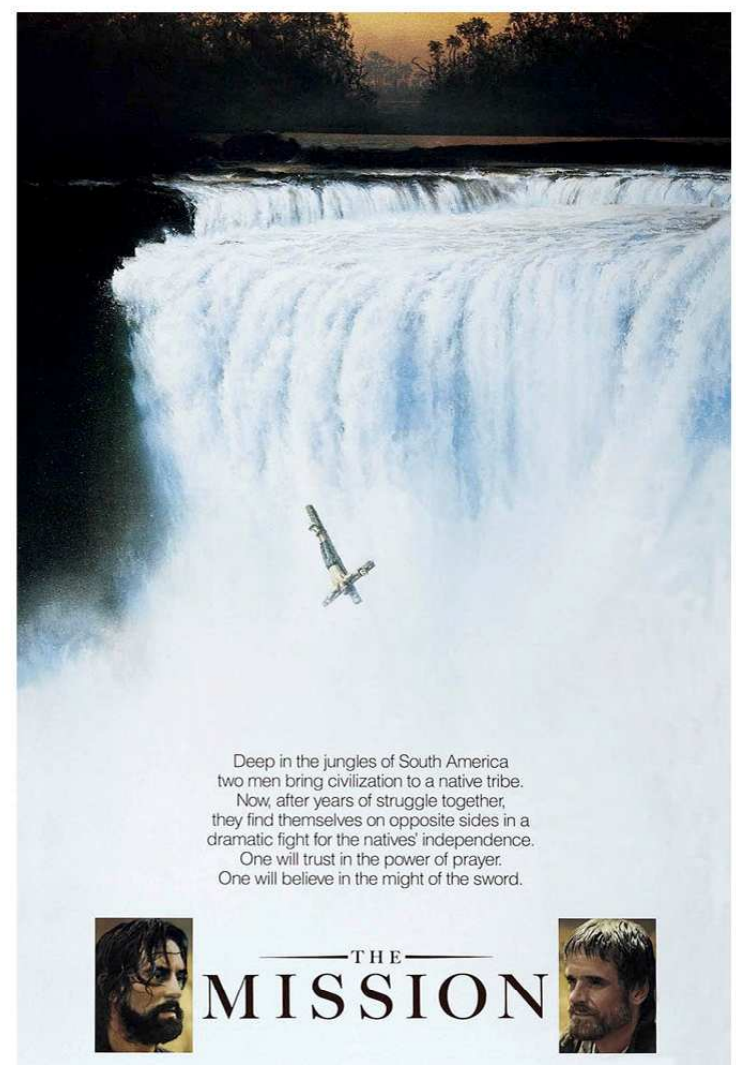

JOFFÉ, Roland (Dir.) Poster do filme A Missão. 1986. Disponível em: http://thelarsenfilmreview.blogspot.com.br/2011/09/mission-1986. $\mathrm{html}$ Acesso em 18 jun. 2015.

\section{A NATUREZA EM}

MISIONES E A

CONSTRUÇÃO DA

IDENTIDADE NACIONAL

NA ARGENTINA:

REPRESENTAÇÕES

IMAGÉTICAS NOS

RELATOS DE EXPEDIÇÕES

PORTENHAS DA

SEGUNDA METADE DO SÉCULO XIX

\section{Bruno Pereira de Lima Aranha}

Mestre em Integração da América Latina pelo PROLAM-USP, área de concentração: Sociedade, Economia e Estado. Graduado e licenciado em História pela Universidade de São Paulo. Iniciou pesquisa sobre a região de Misiones durante o período em que esteve na Universidade de Buenos Aires como intercambista. Atualmente é professor do Colégio Espírito Santo (São Paulo) e assessor pedagógico da Revista Pré-Univesp. 
ARANHA, Bruno Pereira de Lima. A natureza em misiones e a construção da identidade nacional na Argentina: representações imagéticas nos relatos de expedições portenhas da segunda metade do século XIX. Domínios da Imagem, Londrina, v. 9, n. 17, p. 166-195, jan./jun. 2015.

ISSN 2237-9126

\section{Recebido em 16/03/2015 e aprovado em 17/06/2015.}

Resumo: Este artigo consiste numa proposta de análise dos relatos realizados pelos viajantes argentinos Juan Bautista Ambrosetti e Florencio de Basaldúa, que, tendo um ponto de partida em comum - Buenos Aires - se dirigiram a Misiones, no nordeste argentino e publicaram no fim do século XIX textos sobre a região. Através desses relatos temos como intuito desenvolver uma maior compreensão sobre as representações iconográficas acerca da natureza de Misiones que seus autores formularam em seus respectivos relatos. A necessidade de criar tais representações está atrelada à necessidade de construção de símbolos de identidade nacional para a recém-unificada nação Argentina, que naquele momento buscava afirmar sua autoridade em uma região ainda considerada como um lugar recôndito e alheio às influências do poder central de Buenos Aires.

Palavras-chave: Argentina. Misiones. Relatos de Viajantes.

Abstract: This article is a proposal to analyze the reports made by the argentine Juan Bautista Ambrosetti and Florencio de Basaldúa, who, having a starting point in common - Buenos Aires - went to Misiones in northeastern Argentina, and published in the late 19th century texts about the region. Through these reports we have the intention to develop a greater understanding of the iconographic representations of the nature of Misiones that this authors inserted in their respective reports. The need to create such representations is linked to the need of construction of national identity symbols for the newly unified nation (Argentina), which at that time sought to assert his authority in a region still regarded as a secluded place and alien to the influences of the central government of Buenos Aires.

Keywords: Argentina. Misiones. Travel writings.

\section{Introdução}

Situada no nordeste da Argentina, fazendo fronteira com Brasil e Paraguai, Misiones é a província mais oriental do território argentino. É também uma das que mais tardiamente se integrou no processo de construção do Estado nacional em meio ao contexto da política de anexação de territórios ao norte e ao sul de Buenos Aires que ainda não estavam sob o controle efetivo do Estado durante o século XIX. Atualmente é uma província argentina, tendo como capital a cidade de Posadas, mas no 
ARANHA, Bruno Pereira de Lima. A natureza em misiones e a construção da identidade nacional na Argentina: representações imagéticas nos relatos de expedições portenhas da segunda metade do século XIX. Domínios da Imagem, Londrina, v. 9, n. 17, p. 166-195, jan./jun. 2015.

ISSN 2237-9126

período colonial foi ocupada por jesuítas durante os séculos XVII e XVIII. Após a expulsão da ordem religiosa em 1767 e posteriormente à independência do Vice-Reino do Rio da Prata em relação à coroa espanhola, a região de Misiones se encontrou em um complexo contexto de disputas de jurisdição, no qual seu território orbitou sob diversas esferas de influência, tais como a dos caudilhos regionais e também de uma ocupação por parte do Paraguai. Com o desfecho da Guerra da Tríplice Aliança em 1870, os paraguaios foram expulsos da região, que a partir de então foi incorporada como parte da província argentina de Corrientes.

Misiones passou a ter importância para Buenos Aires devido à descoberta de grandes extensões de erva-mate em seu território, o que despertou um ávido interesse econômico, sobretudo no final do século XIX. Devido a este fato, o governo central de Buenos Aires iniciou um processo de desmembramento da província de Corrientes e posterior federalização do território com a intenção de subordiná-lo diretamente ao governo nacional, o que ocorreu no ano de 1881, com a criação do Território Nacional de Misiones.

No fim do século XIX, durante $O$ processo de federalização e ocupação desse território considerado periférico, mas de certo modo estratégico pelo governo de Buenos Aires, várias expedições e viagens foram patrocinadas pelo governo argentino, em busca de maiores informações e relatos sobre essa área de fronteira, ainda pouco explorada, e que, de acordo com a mentalidade da época, era passível de desenvolvimento econômico. As extensas áreas dotadas de erva-mate, a paisagem natural e uma vasta área apta para a colonização chamaram a atenção desses viajantes, conforme seus relatos nos mostram.

No intuito de dimensionar as representações acerca da natureza misionera, alguns desses viajantes lançaram mão da inclusão de 
ARANHA, Bruno Pereira de Lima. A natureza em misiones e a construção da identidade nacional na Argentina: representações imagéticas nos relatos de expedições portenhas da segunda metade do século XIX. Domínios da Imagem, Londrina, v. 9, n. 17, p. 166-195, jan./jun. 2015.

ISSN 2237-9126

representações iconográficas da região em seus relatos. No caso particular dos dois viajantes analisados neste trabalho, suas obras são recheadas de ilustrações. Tratava-se de um olhar diferenciado de outros viajantes que tinham objetivos mais técnicos, como era o caso dos agrimensores enviados pelo governo de Buenos Aires exclusivamente para o fim de mensurar terras'.

Juan Bautista Ambrosetti foi um dos grandes naturalistas argentinos do século XIX, tendo transitado por vários círculos científicos de Buenos Aires e realizado várias expedições pela Argentina, sempre com aval de alguma instituição científica local ou pela via do apoio direto do governo.

Misiones reservou destaque especial para Ambrosetti, já que empreendeu três viagens para essa região, tendo as mesmas dado origem a três relatos distintos. Paralelamente aos relatos de viagem, publicou uma vasta obra de estudos etnográficos dos povos aborígenes de Misiones. Esses estudos pioneiros fizeram com que fosse mais tarde reconhecido como um dos pais da antropologia latino-americana.

A primeira viagem a Misiones é datada de setembro de 1891, tendo explorado a região até fevereiro do ano seguinte. O relato foi publicado em 1892 na Revista del Museo de La Plata. A segunda viagem foi organizada em 1892 pelo mesmo Museu, era a Expedición Nordeste del Museo de La Plata. Devido às credenciais obtidas graças à primeira expedição, Ambrosetti foi incumbido da direção da expedição que ainda era composta pelo francês Emilio Beaufils, responsável pela parte zoológica, e pelo pintor suiço Adolfo Methfessel, responsável pela elaboração de pinturas que posteriormente

\footnotetext{
1 A respeito do uso de imagens como fonte por parte do historiador, Carlos Alberto Barbosa fez um interessante estudo sobre como esse tipo de fonte vem sendo usada desde o surgimento da fotografia no século XIX. A proposta do autor consiste na desconstrução da imagem como uma verdade absoluta, sendo necessário cruzá-la com outras fontes, além de enfatizar o papel do historiador no tocante ao tratamento da historicidade da imagem, suas condições de produção, circulação e apropriação. Procuramos seguir esses pressupostos metodológicos em nosso artigo. Ver Barbosa (s.d.).
} 
ARANHA, Bruno Pereira de Lima. A natureza em misiones e a construção da identidade nacional na Argentina: representações imagéticas nos relatos de expedições portenhas da segunda metade do século XIX. Domínios da Imagem, Londrina, v. 9, n. 17, p. 166-195, jan./jun. 2015.

ISSN 2237-9126

seriam incorporadas ao acervo do Museu (AMBROSETTI, 1894, p.15). O segundo relato foi publicado apenas em 1894.

A terceira expedição teve lugar entre fevereiro e julho de 1894. Além de Ambrosetti, compunham a expedição Juan M. Kyle, do Gabinete de História Natural, e Carlos Correa Luna, gerente dessa mesma instituição. Foi patrocinada pelo Instituto Geográfico Argentino com a finalidade de completar dados sobre a região e colecionar objetos para o acervo do Museu que o Instituto estava preparando. A expedição teve o apoio e o aval do presidente Luis Sáenz Peña, que concedeu passagens até a localidade paraguaia de Tacurú Pucú, no Alto Paraná, além de uma soma de seiscentos pesos (AMBROSETTI, 2008, p. 23-24). O relato da expedição foi publicado em 1896 pelo Instituto Geográfico Argentino.

O nosso outro viajante é Florencio de Basaldúa. Nascido no ano de 1853, em Bilbao, região basca da Espanha, migrou para a Argentina aos 18 anos. Prontamente se converteu em um ator ativo da causa nacional argentina. Ao longo de sua vida, circulou ativamente pela alta sociedade portenha, era membro da Maçonaria Argentina, sócio fundador do Club de Gimnasia y Esgrima La Plata e inclusive cultivou amizade com os presidentes Sarmiento, Roca, Sáenz Peña e José Figueroa Alcorta, entre outros. Em 1910, o presidente Alcorta o designou Cônsul Geral Argentino em Calcutá na Índia. Basaldúa também realizou mensurações nas províncias argentinas de Formosa, Chaco e Misiones. No ano de 1900 foi designado governador interino do então Território Nacional de Chubut, na recém-ocupada Patagônia. Também foi designado pelo governo como representante da Argentina nas Exposições Universais de Chicago (1893) e de Paris em 1900, tendo essa última como temática os produtos das províncias de Entre Ríos, Corrientes e Misiones (REGGINI, 2008, p. 16-18 e 79). 
ARANHA, Bruno Pereira de Lima. A natureza em misiones e a construção da identidade nacional na Argentina: representações imagéticas nos relatos de expedições portenhas da segunda metade do século XIX. Domínios da Imagem, Londrina, v. 9, n. 17, p. 166-195, jan./jun. 2015.

ISSN 2237-9126

A expedição rumo a Misiones foi empreendida entre 1897 e 1898 e tinha como principal objetivo coletar produtos misioneros para serem expostos na Exposição Universal de Paris em 1900.

Para além da causa científica, também era um dever patriótico. Basaldúa queria fazer jus à cidadania argentina que the havia sido outorgada. Apesar de enfatizar em seu relato que colocava recursos próprios na viagem, sua expedição teve o apoio do Instituto Histórico Geográfico Argentino que Ihe concedeu uma passagem de vapor até Misiones.

Os resultados da expedição foram publicados na obra intitulada Presente, pasado y porvenir del Territorio de Misiones, cujo título bem expressava os objetivos de sua expedição que era o de projetar o porvir da região, indo na direção do pensamento da elite portenha que enxergava o crescimento do país no final do século XIX como um Destino Manifesto Argentino de levar a civilização para uma área até então ignorada e selvagem. (íSOLA, 1996, p. 121).

\section{A natureza misionera como um símbolo de identidade nacional}

Para legitimar a vitória da civilização em Misiones, era necessária a criação de símbolos que pudessem integrar o panteão nacional argentino. A natureza, analisada de uma maneira positiva pelos viajantes, fornecia 0 material ideal para integrar o conjunto de representações do processo civilizatório na região.

Essa mesma estratégia era utilizada pelos pintores românticos dos Estados Unidos da Escola do Rio Hudson. ${ }^{2}$ O processo de consolidação da

\footnotetext{
2 Foi um movimento artístico ativo entre 1825 e 1880, formado por um grupo de pintores paisagistas baseados em Nova lorque - onde se localiza a desembocadura do rio Hudson cuja visão estética representou uma síntese entre os princípios do Romantismo e do
} 
ARANHA, Bruno Pereira de Lima. A natureza em misiones e a construção da identidade nacional na Argentina: representações imagéticas nos relatos de expedições portenhas da segunda metade do século XIX. Domínios da Imagem, Londrina, v. 9, n. 17, p. 166-195, jan./jun. 2015.

ISSN 2237-9126

nação do Norte era concomitante ao que estava se passando na Argentina. Influenciados pelos ideais do romantismo, os pintores estadunidenses criaram representações iconográficas que legitimavam o poder civilizatório da natureza selvagem do Oeste. Suas obras buscavam ressaltar a magnitude dessa natureza. Nesse sentido, a ideia era a de mostrar a superioridade da natureza americana em relação à europeia. O exemplo da maneira como representavam iconograficamente lugares como as Cataratas do Niágara e - Grand Canyon, caminhava no sentido de uma criação de símbolos constituintes de identidade nacional.

No caso argentino, para além do relato puramente escrito, os viajantes acoplaram representações iconográficas em suas obras, tanto através de pinturas quanto na forma de fotografias. Acreditamos que analisar a maneira sobre como realizaram essas representações, seja uma forma de compreender o papel que a natureza de Misiones teve no que tocava ao fornecimento de elementos identitários para a nação argentina. No plano simbólico, tais representações também teriam o efeito pragmático de integrar definitivamente a região ao seio da nação.

Da mesma maneira que os pintores estadunidenses buscaram inspiração na natureza para a criação de símbolos nacionais, os viajantes portenhos também recorreram a essa estratégia. A geografia de Misiones favorecia esse intuito. A sua riqueza hídrica e sua selva subtropical eram elementos que discrepavam dos pampas buenairenses - região de origem dos viajantes - dotado de uma vasta planície e de vegetação mais rasteira. O grande símbolo da natureza misionera eram as Cataratas do Iguaçu que representavam o elemento ideal para a criação da simbologia reivindicada

Realismo. O grupo não era formalizado, mas se uniu num espírito de fraternidade, sendo que alguns excursionavam juntos para $\circ$ oeste dos Estados Unidos. Para uma análise mais minuciosa sobre o assunto, ver Prado (1999). 
ARANHA, Bruno Pereira de Lima. A natureza em misiones e a construção da identidade nacional na Argentina: representações imagéticas nos relatos de expedições portenhas da segunda metade do século XIX. Domínios da Imagem, Londrina, v. 9, n. 17, p. 166-195, jan./jun. 2015.

ISSN 2237-9126

pelos viajantes. O momento da chegada a esse atrativo natural representava o ápice das expedições.

Um dos principais objetivos da segunda expedição de Ambrosetti era justamente $\mathrm{o}$ de poder atingir as cataratas, já que na primeira viagem tal empreitada não foi possível de ser realizada. No segundo relato, a parte iconográfica reservou um grande destaque para as cataratas. São sete páginas que se referem a elas e ao rio Iguaçu, contendo nove fotos e uma pintura, cuja autoria é do pintor suiço Adolf Methfessel.

Para entendermos as preocupações de Ambrosetti no que tocava às representações iconográficas da natureza misionera, torna-se necessário analisarmos a problemática sobre como o viajante organizou as equipes que o acompanharam em suas três expedições, sobretudo compreender a importância dos componentes responsáveis pelos registros iconográficos. Nas três expedições, procurou realizar muitos registros fotográficos da natureza misionera. Quando não era ele mesmo o fotógrafo, outros membros da expedição eram designados especificamente para tal tarefa. No caso da segunda expedição, foi acompanhado por Methfessel, cuja responsabilidade era a de realizar registros iconográficos para o Museo de La Plata, instituição patrocinadora da expedição.

Quando chegou às Cataratas, expressou a opinião de que era impossivel tentar retratar tamanha maravilha da natureza. No entanto, suas palavras vão mais em direção da influência do romantismo literário do que da não possibilidade da representação iconográfica em si:

iiObra magna de la Naturaleza americana, conjunto incomparable de belleza, cuadro imponente de majestade salvaje, te saludo entusiasmado como hijo de esta América que te posee en su sueno!!

Los acordes de la lira del poeta se apagan ante tus horrendos bramidos; los pinceles del artista no encontrarán en la paleta los tintes para copiar tus magnificas iridescencias; la pluma del 
ARANHA, Bruno Pereira de Lima. A natureza em misiones e a construção da identidade nacional na Argentina: representações imagéticas nos relatos de expedições portenhas da segunda metade do século XIX. Domínios da Imagem, Londrina, v. 9, n. 17, p. 166-195, jan./jun. 2015.

ISSN 2237-9126

escritor se quebra en un movimiento de desesperada impotencia al quererte describir y hasta la fiel fotografia al transportar tus soberbios contornos, te presentará frío, sin tu inmenso movimiento, el estampido de tua aguas y la brillantéz gloriosa de tus bellísimos arco íris! (AMBROSETTI, 1894, p. 127128).

O romantismo também se faz presente na pintura de Methfessel. Embora Ambrosetti tenha inserido apenas uma obra do pintor suíço em seu relato (figura 1), ela faz parte de um conjunto maior de obras sobre Misiones que foram encomendadas por Perito Moreno para integrar o acervo do Museo de La Plata.

\section{Figura 1}

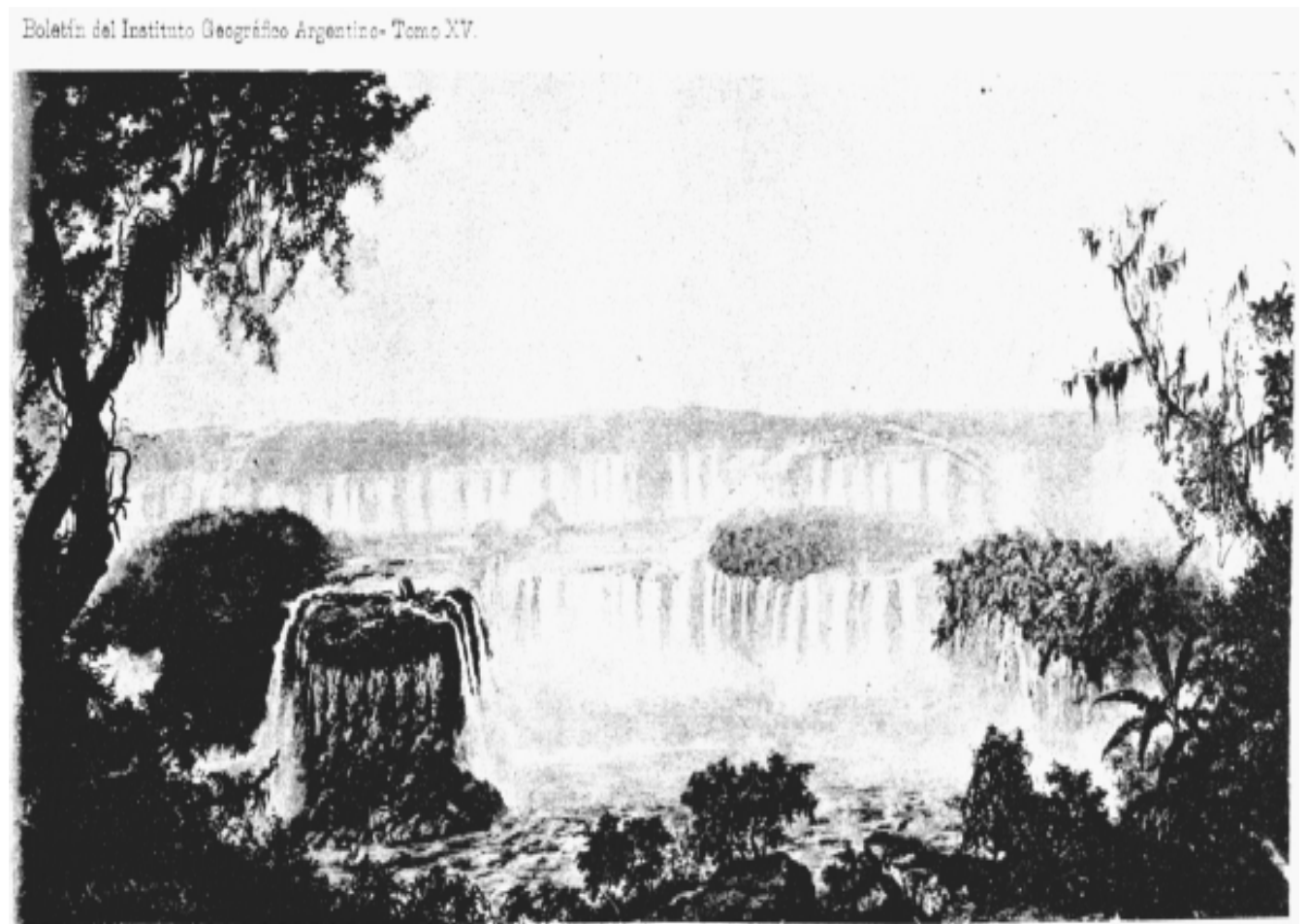

J. B. Antitceets - 20 Vis, \& Whioted

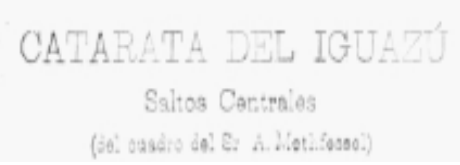

METHFESSEL, Adolf. Catarata del Iguazú - Saltos Centrales. Reproduzido em Ambrosetti (1894, p. 124) 
ARANHA, Bruno Pereira de Lima. A natureza em misiones e a construção da identidade nacional na Argentina: representações imagéticas nos relatos de expedições portenhas da segunda metade do século XIX. Domínios da Imagem, Londrina, v. 9, n. 17, p. 166-195, jan./jun. 2015.

ISSN 2237-9126

Para uma melhor compreensão da citada obra de Methfessel, vemos a necessidade de contar um pouco sobre a trajetória do pintor em terras argentinas. A sua origem suiça é um indício sobre o quanto o romantismo alemão de Goethe o influenciou em sua formação. Em 1864, chegou à Argentina a convite do presidente Domingo Faustino Sarmiento (ARENAS, 2002-2003, p.191). Sua missão tinha um objetivo claro: colaborar na elaboração de símbolos para a construção da nação argentina idealizada por Sarmiento.

Sendo assim, cabe-nos perguntar: a que projeto de nação Methfessel estava a serviço?

Para responder a essa questão, é necessário analisar a conjuntura histórica que vivia a Argentina no período da chegada do pintor, dividida entre os que advogavam pelo poder centralizado em Buenos Aires (unitários) e os que defendiam uma maior autonomia para as províncias do interior (federalistas). O período em que Sarmiento estava no governo correspondia à ascensão do Partido Unitário ao poder após o período de governo de Rosas, representante do Partido Federal. Se alguns anos antes, em sua obra intitulada Facundo, o presidente-escritor realizava uma literatura combativa com o claro intuito de derrubar o inimigo federalista, durante a sua gestão como presidente, pensava ser necessário "sepultar" as lembranças daquele período que remetia à barbárie. Nesse sentido, Methfessel foi convocado a elaborar um projeto de construção de um parque que seria construído sobre as ruínas da antiga chácara de Rosas (ARENAS, 2002-2003, p. 192). Seria a representação simbólica da vitória da civilização sobre a barbárie e o atraso representado pelos federalistas e seus costumes atrelados ao modelo de vida gaucho. O fato de o local ter sido batizado como o nome de Parque 3 de Febrero carrega uma enorme carga simbólica, já que rememorava a data da ocorrência da Batalla de Caseros, marco da queda de Rosas ante 
ARANHA, Bruno Pereira de Lima. A natureza em misiones e a construção da identidade nacional na Argentina: representações imagéticas nos relatos de expedições portenhas da segunda metade do século XIX. Domínios da Imagem, Londrina, v. 9, n. 17, p. 166-195, jan./jun. 2015.

ISSN 2237-9126

o Ejército Grande, uma coalizão composta por unitários, brasileiros, uruguaios e dissidências do próprio Partido Federal.

Em 1876, Methfessel ilustrou a obra Description Physique de la République Argentine d'après des observations per-sonnelles et étrangères, escrita pelo viajante alemão Carlo Burmeister sob encomenda do governo argentino. Quando esteve em Misiones junto a Ambrosetti, realizou uma série de obras sobre os índios káingang, além de imagens idealizadas da selva misionera e das Cataratas do Iguaçu (ARENAS, 2002-2003, p. 197). Segundo Arenas, a idealização da natureza presente nas obras de Methfessel era fruto da influência direta do romantismo alemão:

Los dibujos de Methfessel responden al paisagismo alemán romántico, con elementos desmesurados en primer plano, fuertes claro oscuro, la luz muy difusa y grandes estallidos de color. La naturaleza fue dibujada con la estrategia de un registro naturalista diferenciando una especie vegetal de otra e introduciendo en los paisajes la fauna local. Los pocos seres humanos que aparecen representados lo son en una escala pequeña, en medio de una naturaleza que empequenece. (ARENAS, 2002-2003, p. 197).

Dessa maneira, é também possível traçar um paralelo entre a obra de Methfessel e as obras dos pintores românticos da Escola do Rio Hudson. A ideia de exacerbar a opulência da natureza diante do homem, sempre representado com pequenas proporções, compunha o ideário da confecção de símbolos nacionais, tanto para a Argentina, como para os Estados Unidos. Em ambos os casos, a natureza representava um importante componente do processo civilizatório. Ao mesmo tempo em que, glorificavam a natureza, também engrandeciam a pátria. No caso de Methfessel, sua própria trajetória na Argentina apontava o quanto estava a serviço da construção de símbolos com vistas a compor o panteão nacional argentino. A inserção de sua pintura no relato de Ambrosetti mostrava o 
ARANHA, Bruno Pereira de Lima. A natureza em misiones e a construção da identidade nacional na Argentina: representações imagéticas nos relatos de expedições portenhas da segunda metade do século XIX. Domínios da Imagem, Londrina, v. 9, n. 17, p. 166-195, jan./jun. 2015.

ISSN 2237-9126

quanto o viajante estava preocupado com a ideia da representação do símbolo misionero, que a partir de então, para além de uma esfera regional, se tornaria um símbolo nacional de fato. No plano simbólico, representava a efetiva integração de Misiones ao território nacional, já que um dos maiores símbolos da natureza argentina era misionero.

Para além da representação iconográfica, o fator comparação era outro importante dado incutido no discurso dos viajantes no tocante ao engrandecimento das cataratas. Cabe então indagar: qual seria o parâmetro dessa comparação?

$\mathrm{Se}$ alguns pensadores estadunidenses intencionavam legitimar a natureza do seu continente como superior a europeia, os viajantes argentinos realizaram essa argumentação tendo como parâmetro de comparação, a própria natureza dos Estados Unidos. Basaldúa realizou tal argumentação ao comparar o Paraná, principal rio misionero, ao Mississipi, segundo maior rio da nação do Norte:

He recorrido gran parte del valle del Mississipí hasta su desembocadura en el golfo de México, y puedo asegurar que por la profundidad, anchura y navegabilidad de su cauce, el Paraná es infinitamente superior al Missisipí.

¡Paraná!, yo te saludo! (BASALDÚA, 1901, p. 12).

Também registrou tal comparação no que tocava às Cataratas. Nesse caso, o parâmetro eram as Cataratas do Niágara, grande símbolo da natureza estadunidense. Uma vez mais, a tônica do exagero foi usada para justificar a grandeza de um símbolo nacional argentino, já que o Niágara era comparado a uma situação discrepante entre o Riachuelo, pequeno rio situado em Buenos Aires, dotado de uma largura média de apenas 35 metros, e o caudaloso rio da Prata, o mais largo do mundo com $219 \mathrm{~km}$ de largura: "[...] Cataratas del ú-guazú, á cuyo lado el Niágara famoso es como 
ARANHA, Bruno Pereira de Lima. A natureza em misiones e a construção da identidade nacional na Argentina: representações imagéticas nos relatos de expedições portenhas da segunda metade do século XIX. Domínios da Imagem, Londrina, v. 9, n. 17, p. 166-195, jan./jun. 2015.

ISSN 2237-9126

el Riachuelo de Barracas al lado del Rio de la Plata."(BASALDÚA, 1901, p. 171).

Para legitimar a superioridade das Cataratas do Iguaçu frente ao Niágara, Balsadúa recorreu às descrições de Sarmiento e François-René de Chateaubriand ${ }^{3}$ sobre $~$ Niágara, quando lá estiveram: "Para que los lectores argentinos puedan comparar y darse cuenta exacta de la superioridad de las cataratas del ú-guazú sobre la famosa del Niágara, damos el fotograbado de la gran catarata norte-americana (...) y las descripciones que inspiró á Chateaubriand y á Sarmiento." (BASALDÚA, 1901, p. 165).

É curiosa a estratégia de Basaldúa, já que as descrições de Sarmiento e Chateaubriand são fortemente influenciadas pelo romantismo, ambas narrativas são emotivas e descrevem de maneira extremamente positiva a magnitude do Niágara.

Aqui apresentamos a transcrição que Basaldúa realizou do relato de Chateaubriand:

[...] La masa del rio que se precipita hacia el mediodia, se redondea á mañera de un cilindro inmenso, y desplegándose luego como una cortina de nieve, resplandece al sol con todos los colores, mientras la que se despeña hacia el Oriente baja en medio de una sombra espantosa, á semejanza de una columna del diluvio. Mil arco-iris se conservan y cruzan sobre el pavoroso abismo. Las aguas, al azotar los extremecidos peñascos, saltan en espesos torbellinos de espuma que se levantan sobre los bosques, cual los remolinos de un vasto incendio. Los pinos, los nogales silvestres y las rocas cortadas á manera de fantasmas, decoran aquella escena sorpréndente; las águilas arrastradas por la corriente del aire, bajan revoloteando al fondo del antro, y los carcajús se suspenden por sus flexibles colas de la extremidad de una rama para coger en el abismo los mutilados cadáveres de los alces y osos. (BASALDÚA, 1901, p. 165-166).

${ }^{3}$ Chateubriand - que além de escritor, era também diplomata - esteve no Niágara em 1791. Suas impressões foram registradas na obra Voyage En Amérique.Sarmiento esteve em 1847, e registrou sua passagem pelo Niágara em Viajes. 
ARANHA, Bruno Pereira de Lima. A natureza em misiones e a construção da identidade nacional na Argentina: representações imagéticas nos relatos de expedições portenhas da segunda metade do século XIX. Domínios da Imagem, Londrina, v. 9, n. 17, p. 166-195, jan./jun. 2015.

ISSN 2237-9126

No caso de Sarmiento, sua visão sobre tal fenômeno da natureza foi um dos pontos que o influenciaram na escolha dos Estados Unidos como uma nova centralidade e um novo modelo de civilização para a Argentina.

Abaixo temos dois fragmentos reproduzidos por Basaldúa do relato de Sarmiento sobre o Niágara:

Describir escena tan estupenda sería empeño vano. Lo colosal de las dimensiones atenúa la impresión del pavor, como la distancia de las estrellas nos las hace aparecer pequeñas. (BASALDÚA, 1901, p. 166).

[...] Colocado en el fondo de esta galería singular, aturdido, anonadado por el ruido, recibiendo sobre el cuerpo la caida de gruesos chorros de agua, ve uno delante de sí una muralla de cristal que creyera dura y estable, si las filtraciones de gotas no acusaran la presencia del líquido elemento salido de aquel húmedo infierno: volvendo á ver de nuevo el sol y el cielo, puede decirse que el corazón ha apurado la sensación de lo sublime. Una batalla de doscientos mil combatientes no causaría emociones más profundas. (BASALDÚA, 1901, p. 167168).

Logo, cabe-nos a seguinte indagação: qual seria a intenção de Basaldúa em transcrever em sua obra esses dois relatos extremamente positivos sobre o Niágara?

Em seu relato, logo a seguir às duas citações, o viajante teve por intenção mostrar o quanto as Cataratas do Iguaçu eram ainda mais opulentas em relação à sua congênere do Norte. Embora não apresentasse os dados de medição, para ele, as Cataratas do Iguaçu teriam uma força motriz dez vezes superior às do Niágara, cujos dados de medição realizados por Carl Wilhelm Siemens aparecem no relato:

Así como la belleza natural de las cataratas del Ú-guazú, con su esplendoroso marco de flores, de isipós y de orquídeas, bajo el dosel de un cielo espléndido, es inmensamente superior á la belleza del Niágara, encuadrada en la sombría vegetación 
ARANHA, Bruno Pereira de Lima. A natureza em misiones e a construção da identidade nacional na Argentina: representações imagéticas nos relatos de expedições portenhas da segunda metade do século XIX. Domínios da Imagem, Londrina, v. 9, n. 17, p. 166-195, jan./jun. 2015.

ISSN 2237-9126

boreal; así también la fuerza de las mil cascatas en que se subdivide el ú-guazú es por lo menos diez veces mayor que su rival norte-americana, que el sábio Siemens há estimado en 16 800000 - dieciséis millones ochocientos mil - caballos-vapor.

El magnífico paisaje encierra, pues, tesoro inagotable de fuerzas latentes que en dia no lejano transformarán los ingenieros argentinos en manantiales de civilizacion, llevando á través de una red de cables á todos los ámbitos de la República torrentes de luz, de calor y de fuerza eléctrica recogidos en turbinas al pié de las cascadas. (BASALDÚA, 1901, p. 168).

Balsadúa também lançou mão da iconografia para legitimar essa comparação. Seu relato é composto por cinco grandes fotografias das Cataratas do Iguaçu que ocupam cada uma o espaço de uma página inteira (figura 2), enquanto que a única fotografia do Niágara (figura 3) é dotada de pequenas dimensões, sendo inserida em meio ao texto em que Basaldúa legitimava sua preocupação de maximizar uma posição em detrimento de outra.

Figura 2

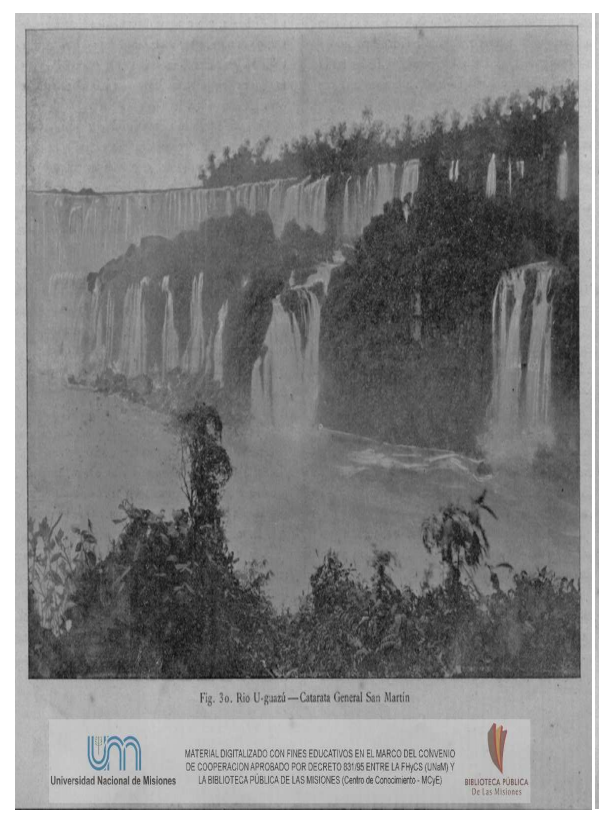

Rio U-guazú - Catarata General San Martin. Reproduzido em Basaldúa (1901, p. 148).
Figura 3

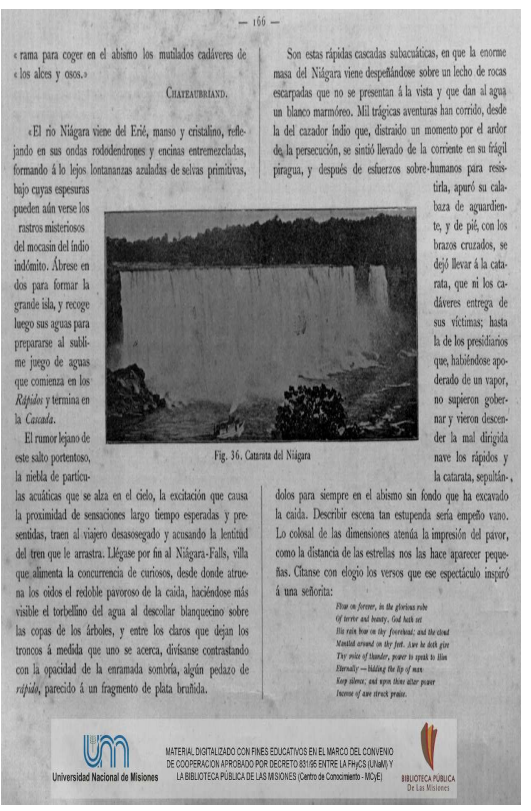

Catarata del Niágara. Reproduzido em Basaldúa (1901, p. 166). 
ARANHA, Bruno Pereira de Lima. A natureza em misiones e a construção da identidade nacional na Argentina: representações imagéticas nos relatos de expedições portenhas da segunda metade do século XIX. Domínios da Imagem, Londrina, v. 9, n. 17, p. 166-195, jan./jun. 2015.

ISSN 2237-9126

Sobre a problemática de uma análise das representações fotográficas, o historiador Rafael Baitz realizou um importante estudo a respeito de como a fotografia esteve inserida no contexto da consolidação dos novos Estados nacionais americanos do século XIX. Seu trabalho diz respeito essencialmente às representações fotográficas inseridas na revista estadunidense National Geographic, entre o final do século XIX e o começo do século XX. Para o autor, a maneira como eram inseridas essas representações na revista, era uma forma de legitimar a grandiosidade e a opulência da natureza do oeste americano em nome da causa nacional dos Estados Unidos:

O meio natural dos Estados Unidos integrou, desde muito cedo, um forte elemento simbólico do nacional. A natureza norteamericana sempre foi, para os artífices do nacional naquele país, um símbolo de forte apelo. E a revista analisada soube, exatamente em um momento de forte ascensão nacionalista, canalizar muito bem esse discurso pré-existente na sociedade. (BAITZ, 2005, p. 236)

Baitz analisou as estratégias utilizadas pela revista para poder criar representações fotográficas que pudessem maximizar as dimensões da natureza dos Estados Unidos. Uma dessas estratégias era a utilização da técnica de tirar fotografias através do ângulo vertical para poder transmitir a sensação de altura de uma queda d'água. Já o uso da figura humana nas fotografias era também uma estratégia usada para estabelecer uma escala de grandiosidade (BAITZ, 2005, p. 239-244). Tal recurso também foi utilizado pelos pintores românticos.

Algumas dessas estratégias também foram utilizadas pelos viajantes argentinos, já que o contexto da consolidação do Estado argentino é 
ARANHA, Bruno Pereira de Lima. A natureza em misiones e a construção da identidade nacional na Argentina: representações imagéticas nos relatos de expedições portenhas da segunda metade do século XIX. Domínios da Imagem, Londrina, v. 9, n. 17, p. 166-195, jan./jun. 2015.

ISSN 2237-9126

contemporâneo ao mesmo processo que ocorreu nos Estados Unidos. O uso de imagens nos relatos dos viajantes era uma forma de atrair a atenção de seus leitores em Buenos Aires para a causa do processo civilizatório que estava ocorrendo em Misiones.

Basaldúa manteve uma grande preocupação com as representações fotográficas. Para além das fotografias presentes no relato, era detentor de uma coleção ainda mais vasta. Em seu relato, assinalou o quanto o presidente Roca e seus ministros "[...] extasiaban sus ojos las bellezas de Uguazú, en la colección de vistas fotográficas que regalé á S.E." (BASALDÚA, 1901, p. 159).

Para além de enxergar a natureza misionera através de uma ótica positiva, era necessário maximizar as percepções a respeito de uma natureza tão diferente da existente na região de origem dos viajantes e de seus leitores. Nesse sentido, a vegetação subtropical de Misiones ganhou destaque especial nas representações fotográficas.

A fotografia das samambaias recebeu certo direcionamento por parte de Basadúa, onde é notada a técnica da inserção de imagens humanas para que o leitor tenha uma ideia da escala da magnitude da planta. A própria legenda escrita por Basaldúa para a foto, reforçou esse intuito: "Helechos gigantescos" (figura 4). 
ARANHA, Bruno Pereira de Lima. A natureza em misiones e a construção da identidade nacional na Argentina: representações imagéticas nos relatos de expedições portenhas da segunda metade do século XIX. Domínios da Imagem, Londrina, v. 9, n. 17, p. 166-195, jan./jun. 2015.

ISSN 2237-9126

\section{Figura 4}

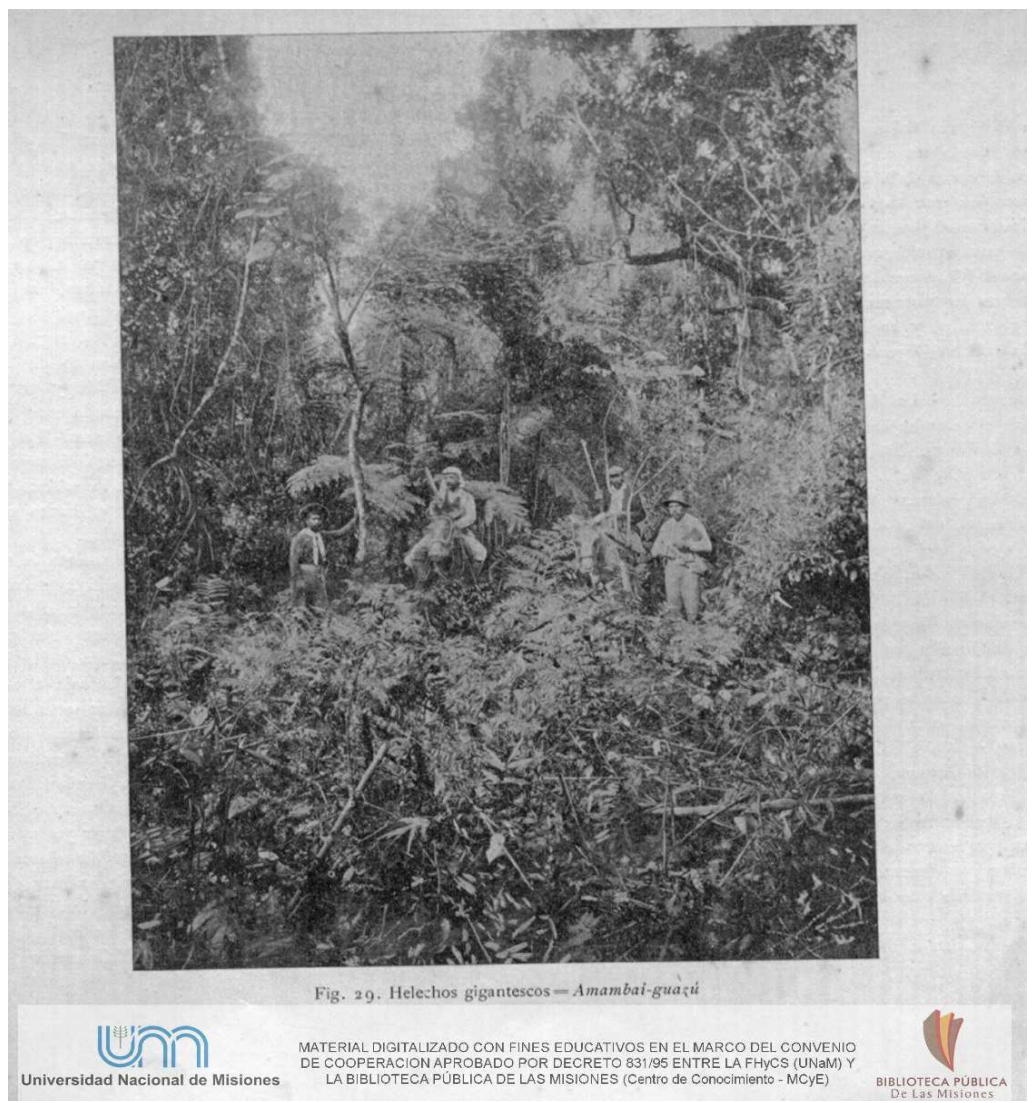

Basaldúa e seus companheiros de expedição em meio às samambaias gigantes. Reproduzido em Basaldúa (1901, p. 145)

Essa mesma estratégia foi utilizada na representação da árvore ñarakatiá. Para isso, utilizou-se de uma foto do acervo de Eduardo Ladislao Holmberg, outro viajante portenho que esteve por Misiones (figura 5), onde ele mesmo é um dos retratados ao pé da árvore.

A importância desse registro fotográfico foi apontada por Basaldúa em seu relato: "He aqui el fotograbado de un árbol de Narakatiá, á cuyo pié se encuentra el doctor Eduardo L. Holmberg que, en su último viaje á Misiones, tuvo la gentileza de retratarse para complacernos" (BASALDÚA, 1901, p. 159). 
ARANHA, Bruno Pereira de Lima. A natureza em misiones e a construção da identidade nacional na Argentina: representações imagéticas nos relatos de expedições portenhas da segunda metade do século XIX. Domínios da Imagem, Londrina, v. 9, n. 17, p. 166-195, jan./jun. 2015.

ISSN 2237-9126

\section{Figura 5}

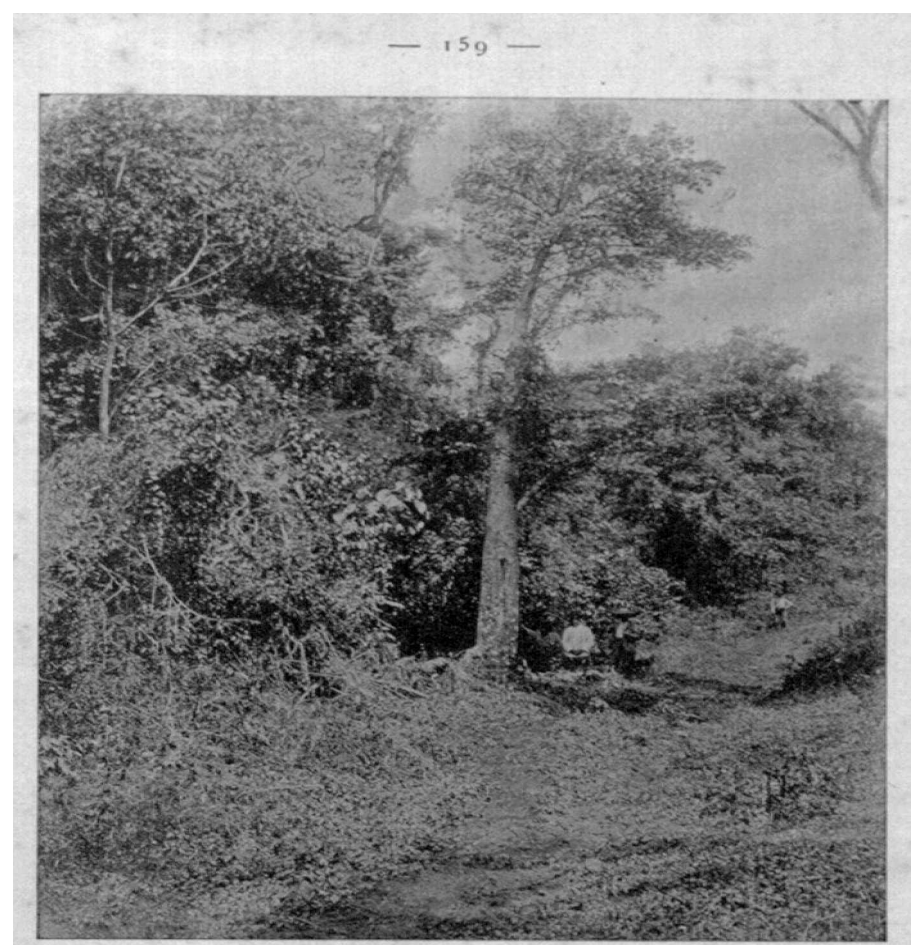

Holmberg e seus companheiros de expedição ao pé de uma árvore de Ñarakatiá. Reproduzido em Basaldúa (1901, p. 159).

Para além de dimensionar a importância da árvore, Basaldúa intencionava mostrar ao leitor o quanto ela poderia ser uma importante fonte de atividade econômica. A própria legenda atribuída à foto de Holmberg -"árbol de los barriles" - dava um claro aviso sobre a utilidade de tal recurso natural. Basaldúa enxergava nela um grande potencial que poderia ser o carro chefe da indústria toneleira argentina, além de ser um alimento nutritivo:

Llevé á Buenos Aires vários troncos de Ñarakatia que reparti en el Ministerio de Agricultura, en el Instituto Geográfico, y entre los grandes diários bonaerenses, para que constataran personalmente el sabor y condiciones nutritivas de la pulpa ó corazón del árbol, y la aplicabilidade de su corteza para construir barricas y barriles de una sola pieza, Léase «EI Tiempo», "Tribuna» y «El País» de 16 Diciembre de 1899, 6 Enero 
ARANHA, Bruno Pereira de Lima. A natureza em misiones e a construção da identidade nacional na Argentina: representações imagéticas nos relatos de expedições portenhas da segunda metade do século XIX. Domínios da Imagem, Londrina, v. 9, n. 17, p. 166-195, jan./jun. 2015.

ISSN 2237-9126

y 22 Febrero de 1900, que refieren las opiniones de sus redactores.

El Excelentísimo señor Presidente de la República probo en mi presencia, en su despacho - como todos sus ministros - trozos de la blanca pulpa [...]" (BASALDÚA, 1901, p. 159).

Ambrosetti manteve a mesma tônica de apresentar fotografias sobre a natureza subtropical de Misiones. As trepadeiras e as samambaias de Misiones foram representadas através de grandes fotografias que ocupavam cada uma o espaço de uma página inteira em seu terceiro relato sobre Misiones (llustrações 6 e 7). Já a representação das árvores de araucária em meio a um pequeno centro urbano, mostrava a intervenção humana em meio à natureza (figura 8).

Figura 6

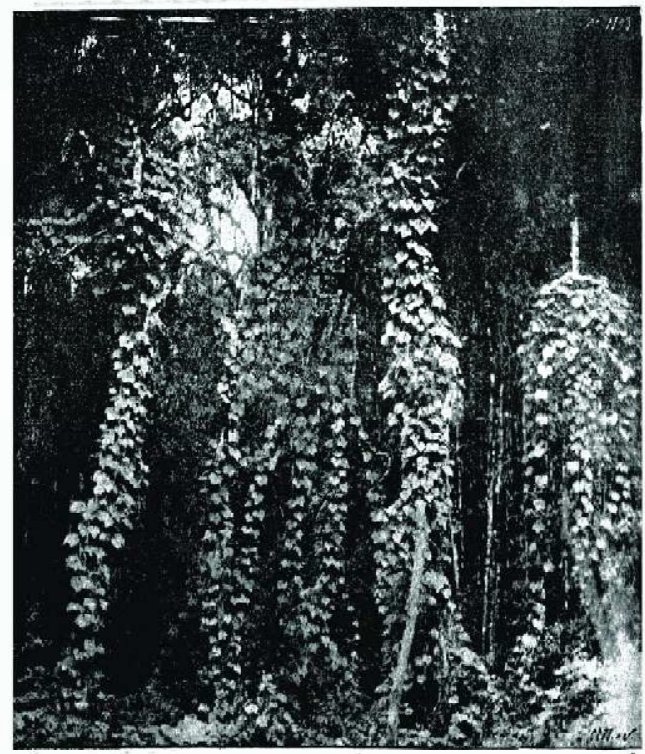

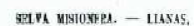

Trepadeiras. Reproduzida em Ambrosetti

(1895, p. 115)
Figura 7

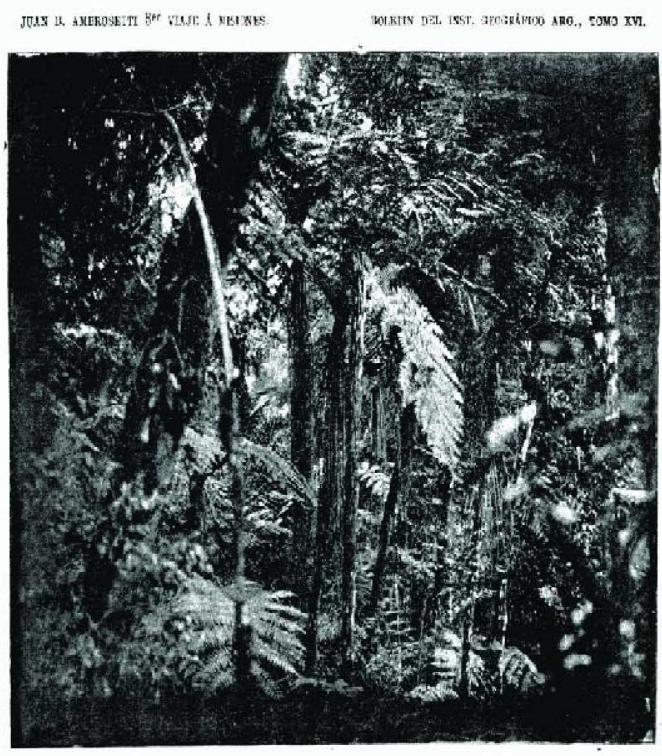

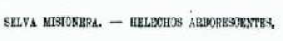

Samambaias. Reproduzida em

Ambrosetti (1895, p. 122) 
ARANHA, Bruno Pereira de Lima. A natureza em misiones e a construção da identidade nacional na Argentina: representações imagéticas nos relatos de expedições portenhas da segunda metade do século XIX. Domínios da Imagem, Londrina, v. 9, n. 17, p. 166-195, jan./jun. 2015.

ISSN 2237-9126

\section{Figura 8}
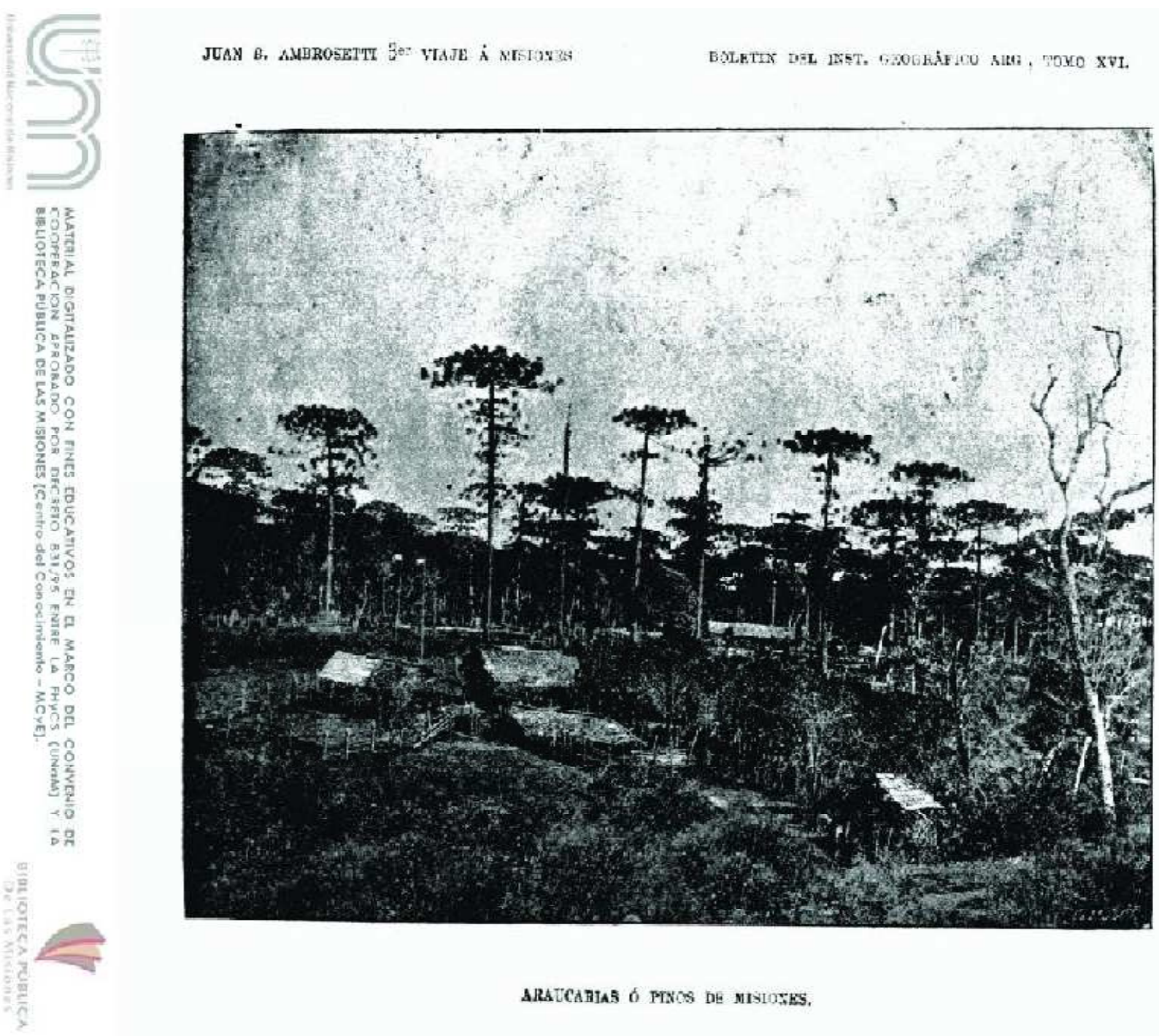

ARATCAFTAS of PINCS DE MISIOFES.

Araucárias na região de San Pedro, próximo à fronteira com o Brasil loeste catarinense). Reproduzida em Ambrosetti (1895, p. 131).

\section{Rumo ao interior: A civilização avança selva adentro}

Tanto Ambrosetti, como Balsadúa registraram em seus relatos uma preocupação de inserir fotos que mostrassem a ação do processo civilizador em Misiones. A presença dos núcleos urbanos no interior do território e a 
ARANHA, Bruno Pereira de Lima. A natureza em misiones e a construção da identidade nacional na Argentina: representações imagéticas nos relatos de expedições portenhas da segunda metade do século XIX. Domínios da Imagem, Londrina, v. 9, n. 17, p. 166-195, jan./jun. 2015.

ISSN 2237-9126

presença dos portos nas margens do Paraná eram representações da presença da civilização na região. A foto das araucárias no relato de Ambrosetti é dotada de um significado especial, já que o núcleo urbano ali representado se localizava na região de San Pedro, área despovoada do interior misionero, localizada na parte leste, junto à fronteira com o Brasil.

Ambrosetti registrou de várias maneiras o embate entre civilização e barbárie em Misiones. As fotografias de um rancho e de um acampamento no meio da selva virgem representavam a ideia de que a civilização estava penetrando a barbárie até então reinante (llustrações 9 e 10).

Figura 9

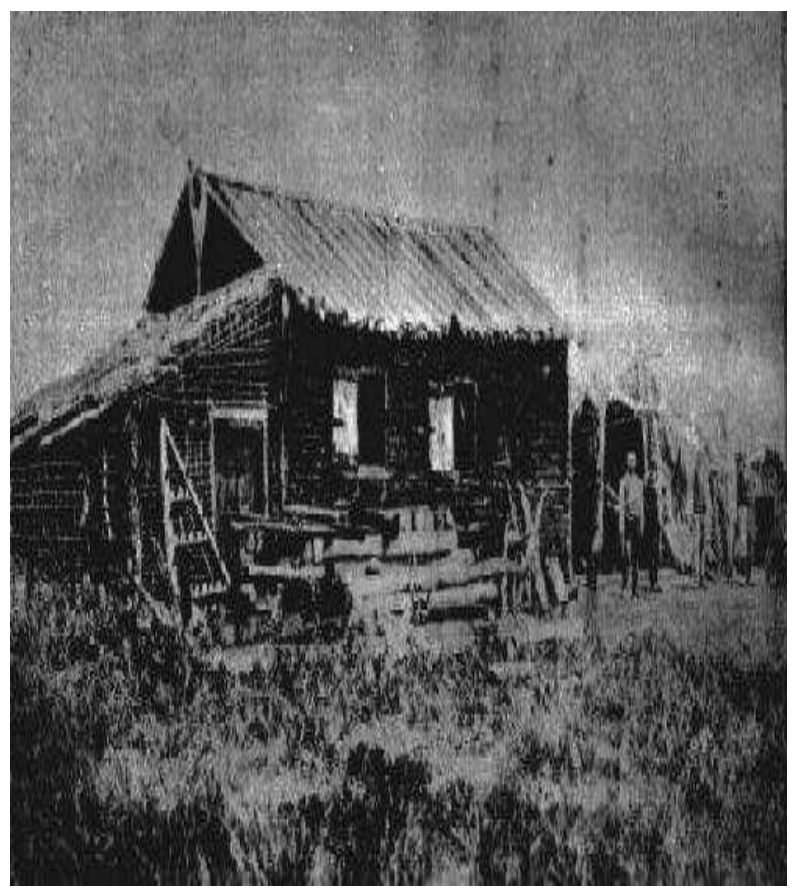

Habitação em Misiones. Reproduzida em Ambrosetti (1892, p. 120).
Figura 10

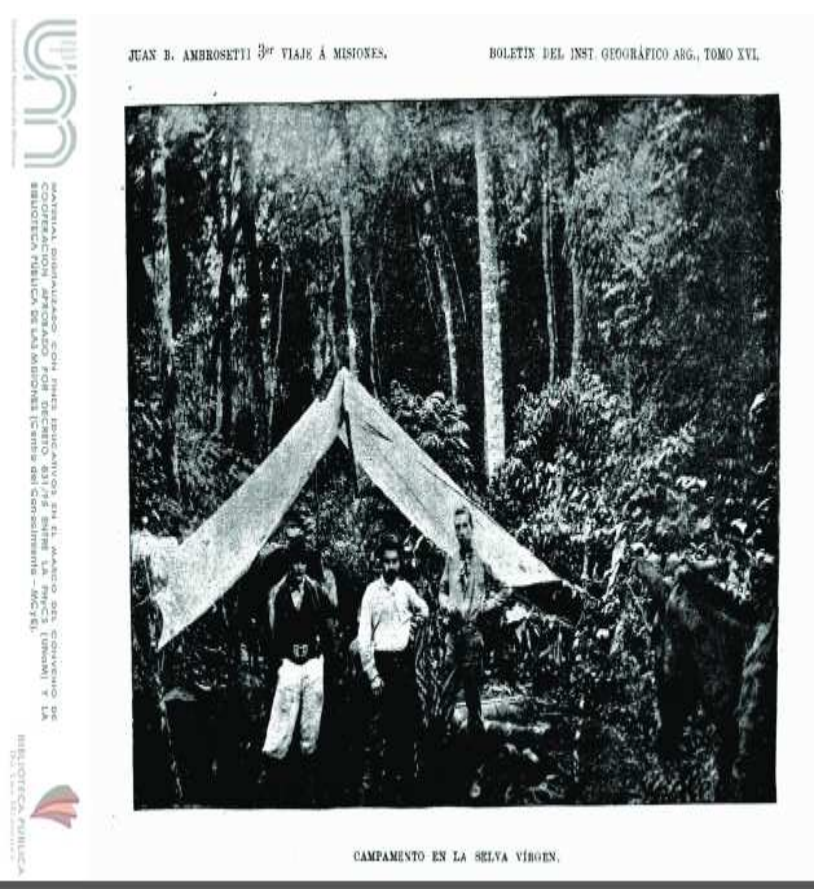

Acampamento da expedição em meio à selva. Reproduzida em Ambrosetti (1895, p. 106) 
ARANHA, Bruno Pereira de Lima. A natureza em misiones e a construção da identidade nacional na Argentina: representações imagéticas nos relatos de expedições portenhas da segunda metade do século XIX. Domínios da Imagem, Londrina, v. 9, n. 17, p. 166-195, jan./jun. 2015.

ISSN 2237-9126

Por outro lado, uma série de quatro fotografias (das quais selecionamos duas imagens) de página inteira das ruínas da antiga missão jesuítica de San Ignacio (llustrações 11 e 12) mostrava o quanto a civilização poderia recuar em meio ao regresso da barbárie. Daí a necessidade do viajante registrar as ruínas sendo encobertas pela vegetação, como se a natureza reclamasse de volta os seus domínios. Era um claro aviso de que o processo civilizatório urgia pelo seu desenvolvimento linear. A rememoração do passado jesútico funcionava como um recado aos leitores sobre como a barbárie poderia retardar o avanço da civilização.

Figura 11

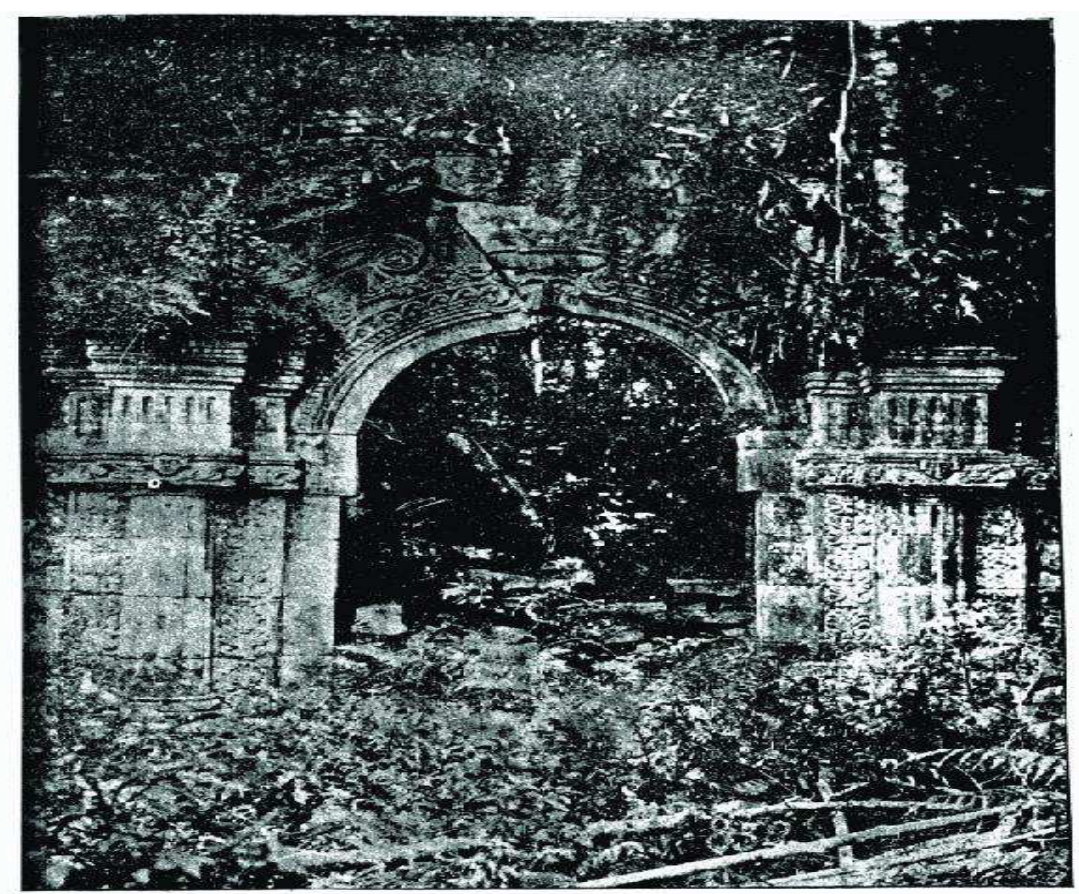

mUINAS DE SAN IGNACIO. - PUERTA TNTERIOR DBL GOTEGIO.

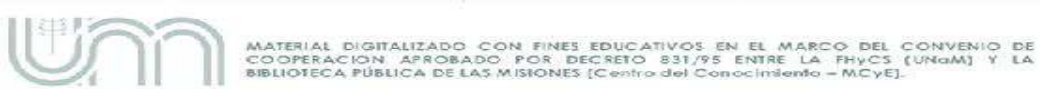

Ruínas da Antiga missão de San Ignacio, no Alto Paraná. Reproduzida em Ambrosetti (1895, p. 66). 
ARANHA, Bruno Pereira de Lima. A natureza em misiones e a construção da identidade nacional na Argentina: representações imagéticas nos relatos de expedições portenhas da segunda metade do século XIX. Domínios da Imagem, Londrina, v. 9, n. 17, p. 166-195, jan./jun. 2015.

ISSN 2237-9126

\section{Figura 12}

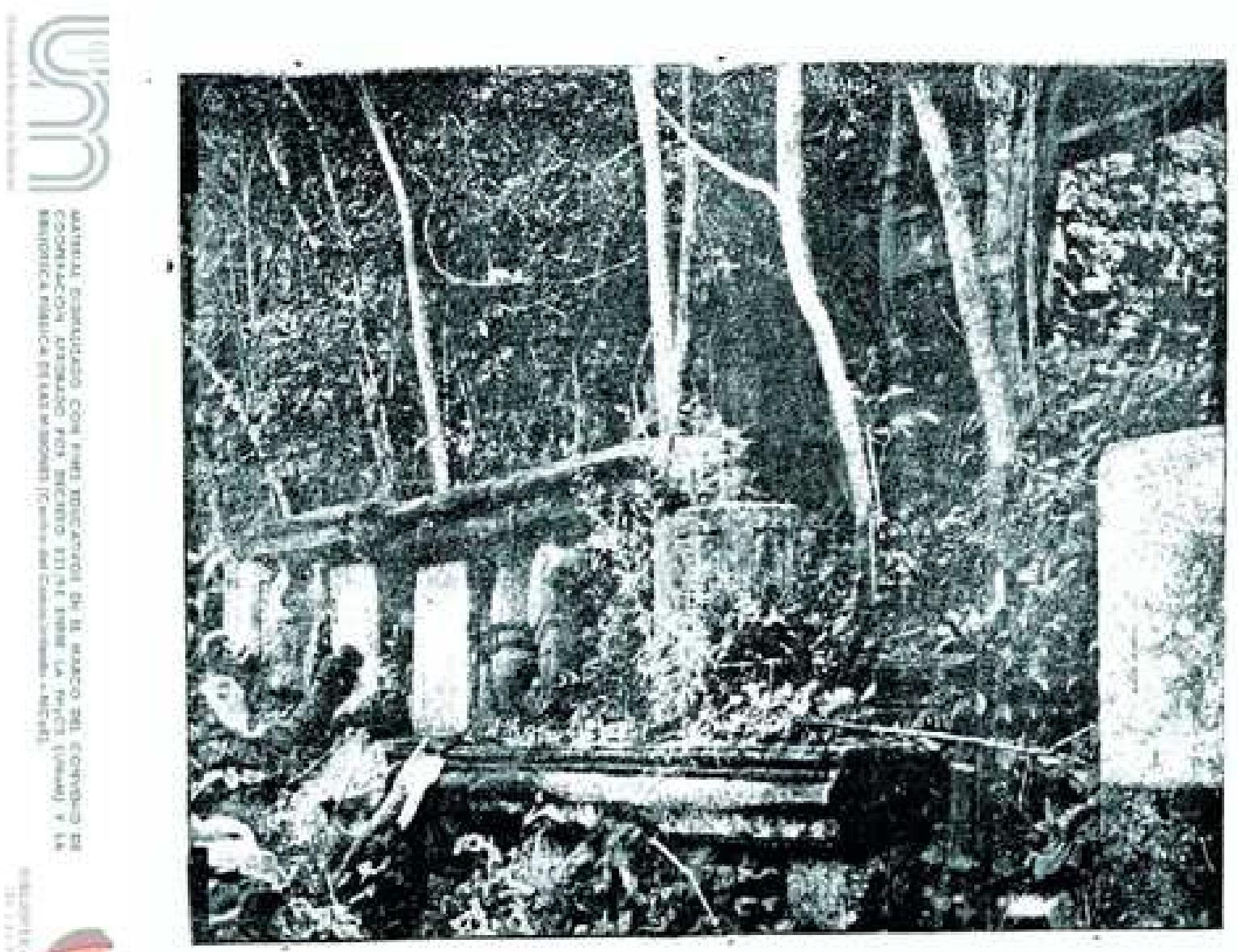

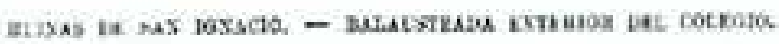

Ruínas da Antiga missão de San Ignacio, no Alto Paraná. Reproduzida em Ambrosetti (1895, p. 71).

No caso de Basaldúa, a imagem cuja legenda diz "Picada en el bosque virgen" (figura 13) representa o avanço do homem em meio à selva misionera. Era necessário retomar o fracassado projeto civilizatório dos jesuítas e reocupar esse território em nome da civilização. No entanto, o viajante não deixou de demonstrar titubeação no momento em que deixava as margens do Paraná em direção ao interior, momento no qual foi necessário a abertura de uma picada em meio à selva. Trata-se de uma 
ARANHA, Bruno Pereira de Lima. A natureza em misiones e a construção da identidade nacional na Argentina: representações imagéticas nos relatos de expedições portenhas da segunda metade do século XIX. Domínios da Imagem, Londrina, v. 9, n. 17, p. 166-195, jan./jun. 2015.

ISSN 2237-9126

descrição dotada de influências do romantismo, onde Basaldúa questionava os avanços da civilização. Até que ponto valeria a pena empreender o processo civilizatório em meio à intocada e bela selva misionera?

Yo sufro cuando veo morir al filo del hacha uno de esos gigantes de la selva, y el chirrido del acero al desprenderse de la húmeda sávia en la madera, para volver á caer una y otra vez más sobre el inerme tronco, semeja gritos de indignación que lanzara un gigante aherrojado, censurando la crueldade del pigmeo que le hiere. Parece que, al caer con estrépito en el suelo, destrozadas las ramas, mustia la flor que un momento antes bebía el sol del cielo, el árbol moribundo me dijera: "Yo poblé sobre la tierra estéril; mis despojos transformados en humus, hánla enriquecido; yo embellecí el triste panorama con las formas esbeltas de mi cuerpo; yo te dí fresca sombra, grato asilo en las cálidas horas de la siesta; yo protegí tus ganados en las heladas noches del invierno; mis flores perfumaron la frente de tu amada; mis frutos fueron manjar sabroso en tus festines; mis ramas alegraron con sus llamas el hogar de tu vivienda ... y me matas ¿̇por qué?.....) (BASALDÚA, 1901, p. 43-44)

Figura 13

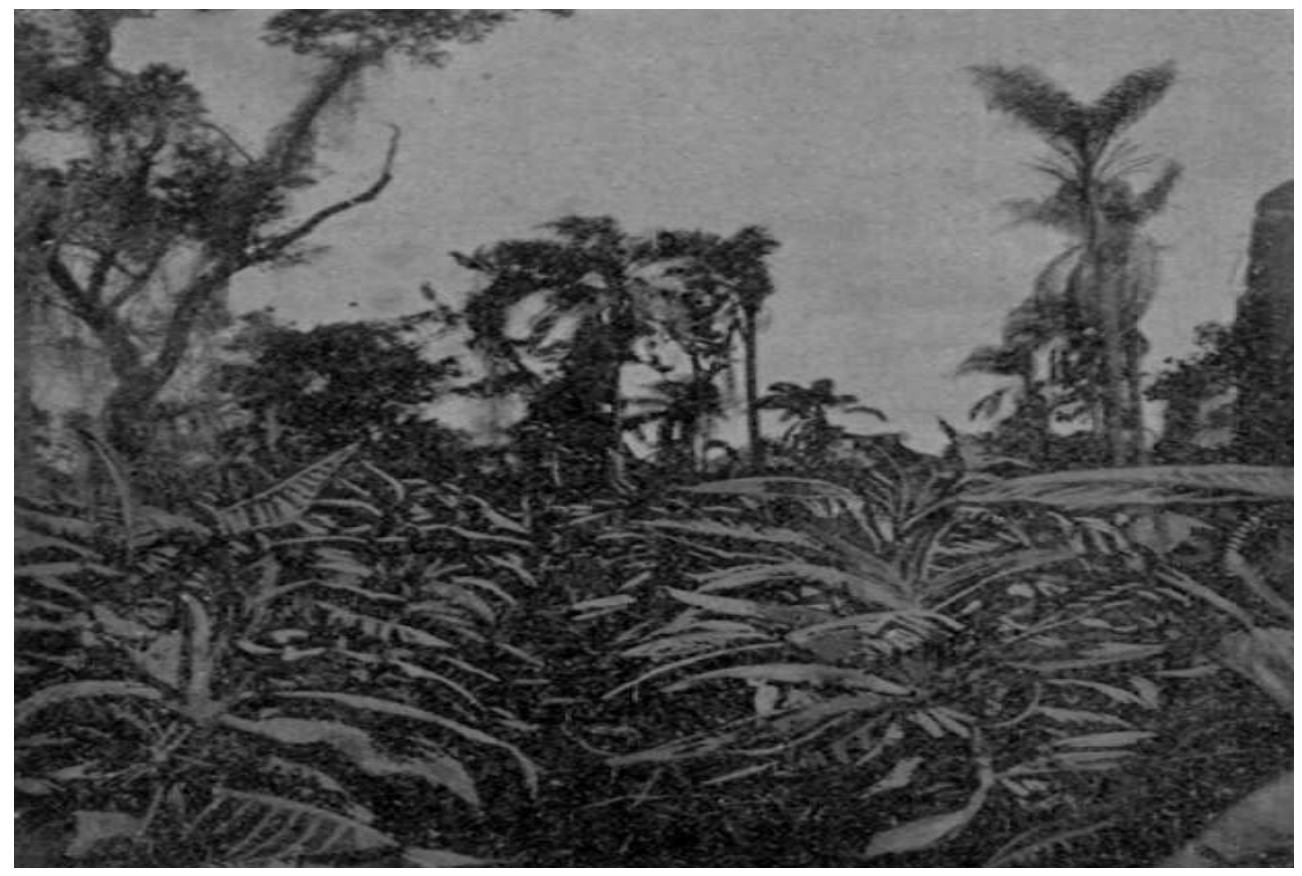

Picada aberta próxima às margens do rio Paraná em direção ao interior da selva misionera. Reproduzida em Basaldúa (1901, p. 43). 
ARANHA, Bruno Pereira de Lima. A natureza em misiones e a construção da identidade nacional na Argentina: representações imagéticas nos relatos de expedições portenhas da segunda metade do século XIX. Domínios da Imagem, Londrina, v. 9, n. 17, p. 166-195, jan./jun. 2015.

ISSN 2237-9126

Também chama a atenção, uma série de fotografias dos portos situados às margens do Paraná, geralmente batizados com os nomes dos pioneers que levaram adiante a sua construção, representando assim um marco simbólico da civilização no Alto Paraná. Era o caso dos portos batizados com os nomes de Bertoni, Blosset e Tarascón (figura 14). Já a fotografia intitulada "Planchada de un obraje" (figura 15) destaca o clarão aberto no meio da floresta com a construção de uma obraje, ${ }^{4}$ representando assim o avanço da civilização em meio à natureza selvagem.

Figura 14

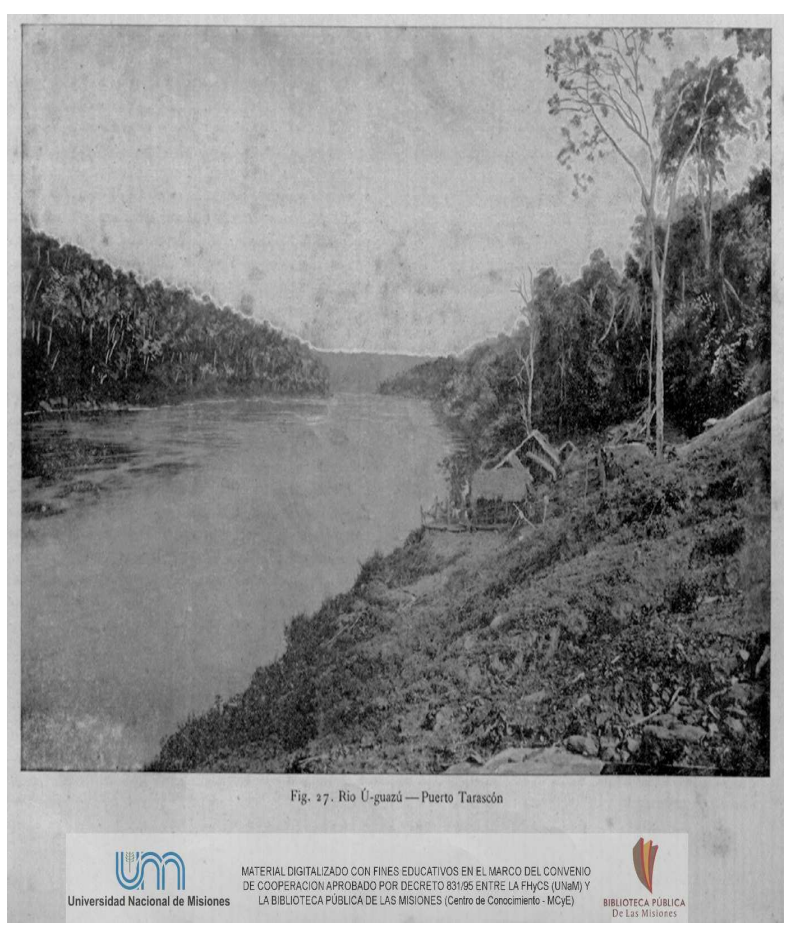

Puerto Tarascón no Rio Iguaçu.

Reproduzida em Basaldúa (1901, p. 143).
Figura 15

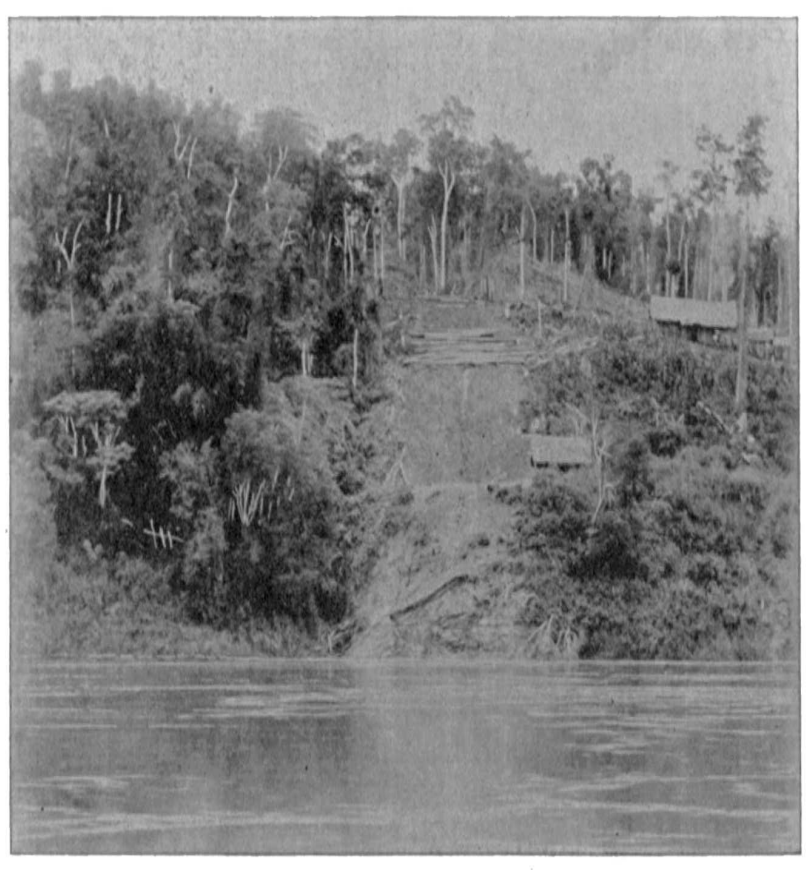

Abertura de uma obraje.

Reproduzida em Basaldúa (1901, p. 143).

\footnotetext{
4 Dava-se o nome de Obrajes (obrage em português) às propriedades destinadas a exploração de erva-mate e madeiras no Alto Paraná e no Alto Uruguai. Por sua vez, os obrajeros eram os proprietários dessas propriedades que geralmente possuíam portos particulares nos rios Paraná e Uruguai com vistas ao escoamento da produção em direção a Buenos Aires.
} 
ARANHA, Bruno Pereira de Lima. A natureza em misiones e a construção da identidade nacional na Argentina: representações imagéticas nos relatos de expedições portenhas da segunda metade do século XIX. Domínios da Imagem, Londrina, v. 9, n. 17, p. 166-195, jan./jun. 2015.

ISSN 2237-9126

Neste sentido, para além das representações românticas a respeito da natureza misionera, os viajantes também usaram a iconografia para representar a natureza como um reservatório de civilização. Tanto Ambrosetti como Basaldúa indicaram através de registros fotográficos, os indícios da presença do homem na selva misionera. As picadas que penetravam o interior da selva, os núcleos urbanos e os portos construídos nas margens do Paraná eram fotografados no sentido de passar ao leitor a ideia concreta de que em Misiones, a civilização havia retomado o seu curso interrompido pela ação fracassada do projeto dos jesuítas.

Em seu estudo sobre as representações inseridas na revista National Geopraphic, Baitz indicou como era planificada a publicação dos textos e imagens na revista. Primeiramente era mostrada a natureza bela e intocada, em seguida, era apontada a importância estratégica da região e por último, eram apresentadas as imagens das transformações realizadas pelo homem. Essas imagens eram constituídas por fotografias de tratores, colheitadeiras, dragas, trens, barragens, usinas e guindastes. Era a representação da ação civilizadora no oeste americano, antes considerado um território obscuro e condenado à barbárie (BAITZ, 2005, p. 239).

Restava-nos então, a seguinte indagação: como seria possível representar tais cenas em Misiones?

O fato era que na altura das expedições dos viajantes, essas ações registradas no oeste estadunidense ainda eram nulas em território misionero. No entanto, era o desejo dos viajantes que tal processo pudesse ocorrer. Seria o curso natural que o progresso deveria tomar em Misiones. Os viajantes mencionaram o futuro que teria a região, que num breve tempo teria povoamento, agricultura e indústria. Basaldúa foi mais adiante ao inserir em seu relato, diversos desenhos de várias máquinas escavadoras e dragas utilizadas na realização da abertura de canais nos Estados Unidos (figura 16). 
ARANHA, Bruno Pereira de Lima. A natureza em misiones e a construção da identidade nacional na Argentina: representações imagéticas nos relatos de expedições portenhas da segunda metade do século XIX. Domínios da Imagem, Londrina, v. 9, n. 17, p. 166-195, jan./jun. 2015.

ISSN 2237-9126

Tais desenhos foram coletados durante a sua estadia na Exposição Universal de Chicago em 1893 (BASALDÚA, 1901, p. 162).

As cinco imagens configuravam uma representação de como o exemplo dos Estados Unidos também deveria ocorrer em Misiones. As imagens são referentes a um projeto idealizado por Basaldúa, de uma construção de um grande canal que pudesse desviar a rota de navegação no Paraná, para que assim fosse possível contornar o obstáculo do Salto do Apipé. Para ele, a construção do canal significava "grandes y legítimas esperanzas de progreso" (BASALDÚA, 1901, p. 55-70). Fomentaria também a indústria e o povoamento da região, parafraseando Alberdi - pensador argentino do século XIX - citou sua famosa frase "Gobernar es poblar" para justificar tal empreitada. (BASALDÚA, 1901, p. 69).

Figura 16

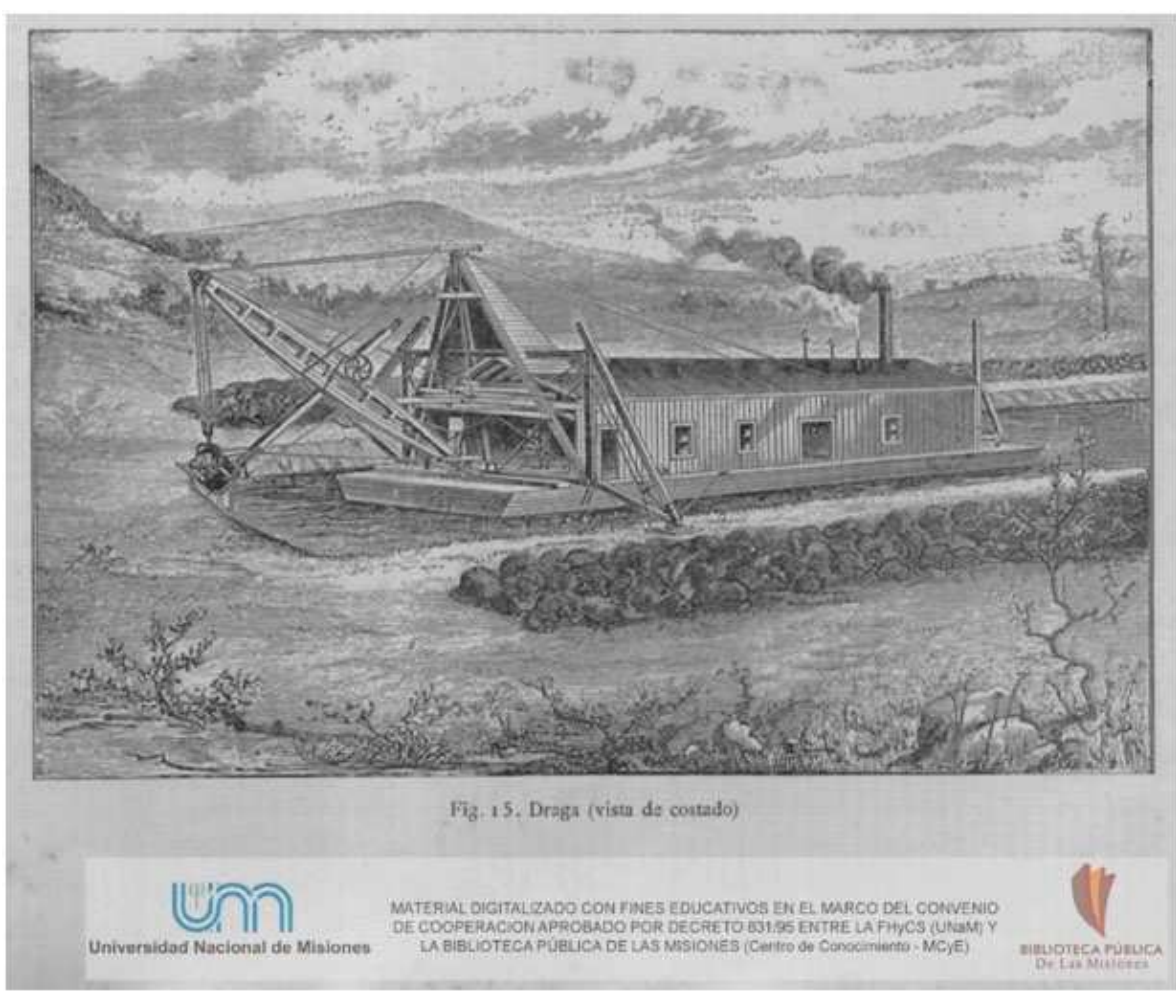

Desenho coletado durante passagem de Basaldúa pela Exposição Universal de Chicago em 1893. Reproduzido em Basaldúa (1901, p. 65). 
ARANHA, Bruno Pereira de Lima. A natureza em misiones e a construção da identidade nacional na Argentina: representações imagéticas nos relatos de expedições portenhas da segunda metade do século XIX. Domínios da Imagem, Londrina, v. 9, n. 17, p. 166-195, jan./jun. 2015.

ISSN 2237-9126

\section{Considerações finais}

Todas essas representações iconográficas sobre a natureza misionera tinham o claro objetivo de poder transmitir aos leitores a ideia de uma construção de símbolos de identidade nacional para a Argentina. Ao mesmo tempo, apresentavam ao público de Buenos Aires, um espaço geográfico totalmente distinto ao de sua origem. Buscava-se transmitir a ideia de que aquela natureza opulenta também Ihes pertencia, e era parte constituinte da nação.

Para além da apreciação puramente associada ao romantismo, era necessário seguir o exemplo dos estadunidenses e domar aquela natureza selvagem. A estratégia utilizada pelos viajantes de dimensionar e comparar os símbolos da natureza misionera com os símbolos da natureza estadunidense era uma forma de impulsionar o processo civilizador. Afinal, se as Cataratas do Iguaçu e o Paraná eram superiores às Cataratas do Niágara e ao Missisípi, significava que a natureza argentina, enquanto reservatório de civilização detinha um poder simbólico superior ao de sua congênere no norte do continente.

Para os viajantes, a iniciativa do processo civilizador em Misiones dependeria exclusivamente da iniciativa dos civilizadores portenhos. Foi essa a tônica do recado transmitido por Basaldúa aos seus leitores:

Nuestra acción cesa aqui. Nuestras débiles fuerzas pecuniárias nos impiden seguir colaborando en la ejecución de la obra, y ofrendamos tan sólo el pensamiento de ella para que los que pueden tengan la gloria de realizarla.

La ganacia es segura.

¡A la obra! (BASALDÚA, 1901, p. 70).

Concluímos que a natureza teve lugar de destaque no discurso dos viajantes. Dentro de uma perspectiva utilitarista, as extensas áreas de erva- 
ARANHA, Bruno Pereira de Lima. A natureza em misiones e a construção da identidade nacional na Argentina: representações imagéticas nos relatos de expedições portenhas da segunda metade do século XIX. Domínios da Imagem, Londrina, v. 9, n. 17, p. 166-195, jan./jun. 2015.

ISSN 2237-9126

mate, a grande quantidade de madeiras e o potencial hídrico da região eram considerados como agentes civilizadores que possibilitariam a chegada do progresso à região, beneficiando não apenas Misiones, mas a nação Argentina como um todo. Era parte de uma estratégia discursiva de incluir uma região até então considerada recôndita e alheia à influência do Estado.

No plano simbólico, a magnitude da natureza misionera representava um elemento de legitimação de identidade nacional. Devido a esse motivo, os viajantes preocuparam-se em inserir representações iconográficas com vista a ressaltar a magnitude das dimensões dessa natureza que a partir de então, não era parte constituinte apenas de Misiones, mas de toda a nação Argentina.

\section{Referências}

AMBROSETTI, Juan Bautista. Misiones Argentinas y Brasileras por el Alto Uruguay. La Plata: Talleres de Publicaciones del Museo, 1892.

AMBROSETTI, Juan Bautista. Misiones - Segundo Viaje por el Alto Paraná é Iguazú. Buenos Aires: Publicado en el Tomo XV del Boletín del Instituto Geográfico Argentino, 1894.

AMBROSETTI, Juan Bautista. Tercer Viaje a Misiones. Buenos Aires: Publicado en el Tomo XVI del Boletín del Instituto Geográfico Argentino, 1895.

AMBROSETTI, Juan Bautista. Tercer Viaje a Misiones. Buenos Aires: Editorial Albatroz, 2008.

ARENAS, Patricia, Naturaleza, arte y americanismo: Félix Ernst Adolf Methfessel (1836-1909). Société suisse des Américanistes / Schweizerische AmerikanistenGesellschaft, Genebra, Boletim 66-67, p. 192-198, 2002-2003.

BAITZ, Rafael, Fotografia e Nacionalismo: A Revista The National Geographic Magazine e a Construção da Identidade Nacional Norte-Americana (18951914), Revista de História do Departamento de História da Faculdade de 
ARANHA, Bruno Pereira de Lima. A natureza em misiones e a construção da identidade nacional na Argentina: representações imagéticas nos relatos de expedições portenhas da segunda metade do século XIX. Domínios da Imagem, Londrina, v. 9, n. 17, p. 166-195, jan./jun. 2015.

ISSN 2237-9126

Filosofia, Letras e Ciências Humanas da Universidade de São Paulo (USP), São Paulo, n. 153, p. 225-250, jun./dez. 2005.

BARBOSA, Carlos Alberto Sampaio. História visual: um balanço introdutório, Cadernos de Seminários de Pesquisa Cultura e Política nas Américas, Assis: FCL-Assis-Unesp Publicações, Vol. 1, p. 72-85, 2009. Disponível em http://historia.fflch.usp.br/sites/historia.fflch.usp.br/files/CSP1.pdf. Acesso em 10 jan. 2015.

BASALDÚA, Florencio de. Pasado - Presente - Porvenir del Territorio Nacional de Misiones, La Plata, 1901.

ÍsOLA, Viviana G. Semblanza de un hombre de Estado: Julio Argentimo Roca, 1880-1914. In: Buenos Aires 1880-1930. La capital de un imperio imaginario. Madrid: Alianza Editorial, 1996. p. 111-125.

PRADO, Maria Lígia Coelho. América latina no século XIX: tramas, telas e textos. São Paulo: Edusp; Bauru: Edusc, 1999.

PRADO, Maria Ligia Coelho. Natureza e identidade nacional na Américas. In: América Latina no século XIX. Tramas, telas e textos. São Paulo; Bauru: Edusp; Edusc 1999.

REGGINI, Horacio. Florencio de Basaldúa, Un Vasco Argentino. Buenos Aires: Academia Nacional de Educación, 2008. 